\title{
INVESTMENT ATTRACTIVENESS OF INDUSTRIES: FEATURES AND TRENDS
}

\author{
Svitlana Gutkevych ${ }^{1}$
}

\begin{abstract}
The article shows that the investment attractiveness of the branches of the economy depends on the sources of their investment. The purpose. The purpose of the article is to determine the features and trends of investment attractiveness of industries. Results. The volume of budget investments has been reduced, and the state is not the main executor of the investment process and can influence it through the system of taxes, loans, depreciation, privileges, and subsidies. It is determined on the basis of the analysis of sources of investment that self-financing is of paramount importance and the main source of investment is its own resources, first of all, profit. The basic functions that make a profit and the factors affecting it are determined. The considered functions directly result from the development of the enterprise and depend on the adoption of investment decisions. The role of the profit in the adoption of an investment decision depends on its type: short-term expected profit is a complete self-financing, which implies the rapid implementation of investments. Profit is the result of the effective operation of any investment object and the basis for making an investment decision. These functions can be considered as classical interdependent because they find content only in the conditions of their existence and contribute to the development of production. The innovation activity of the enterprise determines its potential market opportunities and attractiveness for the investor, and profit growth is ensured mainly due to: production of new products; development of new markets; growth of labour productivity; use of new raw materials. In economically developed countries, the investment process depends on the impact of market conditions, sources and size of investment financing. Attracting investments in any form contributes to the development of the economy. Value/originality. Profit is considered, firstly, as the profit received as a result of production and sales of products or services; and secondly, income in the form of interest or dividends received from the acquisition/investment of securities. In the course of the study, the motivational content of profit as the main source of investment is considered. International experience shows: the volume of foreign investment entering the country's economy determines its integration into the world community.
\end{abstract}

Key words: investment attractiveness, industries, profit, factors, development.

JEL Classification: E22, E27, D24, K23, N50

\section{Introduction}

The general and state climate of the state is determined by many factors, including economic and legal ones.

In this regard, the question of creating investment attractiveness as the basis for management of the investment process requires in-depth theoretical and practical developments. Despite numerous economic developments, the problem of creating investment attractiveness, which is the basis of the investment process, has not been sufficiently comprehensive in the scientific economic literature. In the changed state approach to the country's economic development, there is a need for in-depth research and development of new theoretical and methodological foundations for the development of the investment process, forms and mechanisms for creating investment attractiveness at the micro and macro levels for the purpose of the most effective capital investments.

When making managerial decisions on investment, it is necessary to determine the most priority objects, that is, more efficient investments of capital: in production, securities, real estate, etc.

The current stage is the study of market forms and mechanisms of investment attractiveness at the micro and macro levels. The investment process in Ukraine has its own guidelines and priorities for investment.

The choice of the most effective form of investment begins with the analysis of possible alternative options. At the heart of the comparison are methods for assessing the effectiveness of investment and, above all, indicators of profit, reliability, risk level.

Ukraine at the present stage is a country with a rather low investment rating that determines its

Corresponding author:

${ }^{1}$ National University of Food Technologies, Ukraine.

E-mail: gutkevych@ukr.net 
investment attractiveness, which depends on the level of development of the legislative framework, political situation, efficiency of economic policy, infrastructure development, volumes of direct foreign investment inflow, and a number of other factors. The functions of forming an investment policy and the system of criteria of attractiveness should be performed and provided only by the state. An important foreign policy value for the country is to receive foreign investments since its volume is one of the indicators characterizes the degree of integration of the country into the world community.

It is precisely the lack of knowledge of this issue and, on this basis, the lack of scientifically grounded policy in raising the level of investment attractiveness and clarity in determining priority has a negative impact on the attraction of foreign investments, as well as their impressive use.

\section{Literature review}

Existing researchers in the investment process development in a certain way cover its state in Ukraine. In particular:

A. Pereverzeva (2016) investigated the features of the foreign investments attraction into the Ukrainian economy, which, on the one hand, contributes to the development of the national economy in general and, on the other hand, is an indicator of the conditions and incentive for activation of entrepreneurial activity. Not only the overall state of the country's economy but also the business conditions, in particular, the degree of state intervention and the level of corruption, have a significant impact on investment attractiveness. It has been established that the most attractive sectors for foreign investors are the processing industry, financial activity, trade and real estate operations, leasing, engineering and services to entrepreneurs.

Andre Babot (1993) considered various aspects of profit as one of the main indicators of the activity of any enterprise. On the basis of the theoretical study of profit as a category, the functions that it performs in the economic activity of the enterprise are determined. The author points out that the value of profit as a guide for investment decisions and measures in assessing the effectiveness of management is determined everywhere, regardless of the time, the economic and political system.

O. Kovalenko and K. Tymofieieva (2011) investigated the current state of investment activity in Ukraine and the priority directions of activation of foreign investments.

N. Krihovska and G. Chernyshova (2017) investigated the essence of the concepts of "investment climate" and "investment attractiveness" and their difference. The structure of direct foreign investments into the economy, dynamics of inflow of foreign capital has been expanded. The main problems of attraction of investments into the domestic economy, the state of investment attractiveness of Ukraine according to international rating assessments, as well as directions of increasing the investment attractiveness of the economy were highlighted.

However, the problems of creating investment attractiveness as the main factor in the development of investment activities predetermine the necessity for further research. The state approach to ensuring economic development forms the prospects for the development and implementation of new theoretical and methodological bases for the development of the investment process, the development of mechanisms for the formation of investment attractiveness at the macro level for the embedding of the property and intellectual property in objects of entrepreneurial and other activities, with the purpose of creating profits, achievements, social and environmental impact.

\section{International experience of investment}

One of the factors determining the global economic process is the international interweaving of capital. For Ukraine, attracting foreign investment is important in the context of structural reforms in the economy.

Each economically developed country, as an economic system, has its own model of a market economy, which was formed under the influence of historical traditions, level of economic development, social and national conditions. Economic literature has different approaches to the analysis of types of economic systems.

There is no single standard of models characteristic of economic systems. Each state or region has national models of organization of the economy, as countries differ in historical experience, level of economic development, social and national conditions. This is an American model of the economy, Swedish, Japanese, South Korean and other models that differ significantly from each other. Their study is of practical importance for the correction of Ukraine's development, taking into account the specific conditions prevailing in the country.

In economically developed countries, the investment process depends on the impact of market conditions, sources and size of investment financing. Investing in these countries is carried out at the expense of private capital investments, direct investment from the budget; indirect budgetary subsidization of investment shares, i.e. due to investment loans and tax breaks; investments in social objects from social and charitable foundations.

The state controls, on a legislative basis, certain activities related to national interests: banking, financial, and tax systems and regulates changes in the balance of payments.

World experience has shown that foreign investment has advantages over other forms offinancing of economic development. This is in front of all an additional external source of investments in the production of goods and services, which contributes to the development of the 
economy, while not affecting the state budget and the external debt of the state.

For Ukraine, the experience of different states is important, as the influence of foreign investment on the state's economy in the world is not the same. The analysis of the most important factors influencing the process of attraction of direct foreign investments into the economy of Poland, as the country bordering Ukraine in the west, was conducted. The main ones are: economic transformation; stabilization of economic policy; growth of gross domestic product; participation in the Organization for Economic Cooperation and Development; membership in the European Union. About $90 \%$ of direct investment in Poland comes from the member countries of the Organization for Economic Co-operation and Development. The analysis of the investment process showed that, according to the priority of the sectors of the economy, investments come primarily into the production of food, beverages and tobacco products, that is, the food industry, then the machine building sector. When studying foreign investors, investing one third of them outlined five factors that have a positive effect on investment attractiveness and foreign direct investment in Poland: a good prospect for economic growth of the country; low labour cost; the volume of the Polish market; great supply of labour; the possibility of reducing production costs (Pavlovych, 2000).

The results of the studyindicate that, despite significant progress in many areas of activity, foreign investors are still faced with certain difficulties. When asked about the complexity of starting their business, investors often called the following steps: preparation of the necessary documentation and registration of the company; ensuring the normal technical and organizational conditions for starting a business; the recruitment process of the personnel concerned; obtaining permits for doing business from the relevant authorities; search for business partners. Foreign investors positively assessed the infrastructure in Poland.

The development of Spain's economy as one of the European Union countries, which has achieved significant economic success, is characterized by a change in the import of food products by exporting high-quality products, economic protection, a stable legislative system, tax improvements, and investment attractiveness for foreign investment. The development of the economy of Spain can be divided into four enlarged stages: the post-war period - the path to selfsufficiency; non-competitive growth; stabilization and openness of the market; the stability of the foundations of legislation; the desire for greater openness and increased competitiveness (Fernandes, 1993).

Thus, France does not allow or restrict foreign investment in certain sectors of the economy, for example, in the exploration of mineral resources, mining, and the pharmaceutical industry. The main feature of British policy regarding foreign capital is the desire of the British government to attract foreign direct investment into the country, primarily in the form of advanced foreign technology. The different attitude to foreign investment is determined by the peculiarities of the political and economic development of each country, which is covered in the legislation.

In most Western countries, there are no special laws on foreign investment, they are regulated as national investments, based on the norms of the general legislation. The policy and legislation of the countries of Europe are influenced by the integration processes, the formation of the European Union.

In the eighties, the share of foreign investment in total investment amounted to $20 \%$, and the US food industry developed due to the influence on foreign investors' investment policy. In the same period, to the beginning of the 90s, the annual total investment in the country's food complex amounted to 70-80 billion dollars and $60-64 \%$ - the share of investment. An important feature of the US investment process in the past two decades is an increase in the share of private investment.

The investment policy in the agribusiness sector in Canada and Western Europe is significantly different from the United States. This is primarily due to the structural features of these countries. For example, the main area of the US - is all fund-making industries and the system of production and technical maintenance of agriculture.

In some Western European countries, this area is less developed as a result of regional integration and cooperation, on the basis of which almost entirely meet the needs of farms and the processing industry in logistics. In these countries, the most important statistical indicator of the investment process is the size of capital investments in agriculture and the food industry. The industrial area of Canada is characterized by a trend of cyclical current capital investments with absolute and relative real reduction of investments. Similar tendencies of investment processes are observed in England, Germany, and France.

At present, the investment policy is aimed at the development of industrial infrastructure. In Japan, funds directed at investments contain a high share of bank loans. The investment policy of the European Union defines attractive investment priorities:

- the focus of the investment activity to maximize capital and resource efficiency in all spheres of agribusiness;

- elimination of imbalances in resource potential;

- reduction of commodity deficit of products of the agro-industrial complex on the consumer market.

Like every country, Ukraine will have its own model of a market economy, which should be formed taking into account historical traditions, demographic features, specific conditions of development of the country, based on the rational combination of different forms of ownership and management. 


\section{Regulation of investing}

The development of industries requires the intensification of investing on the basis of the investments attraction, both domestic and foreign. The dynamics of the investment process in Ukraine is characterized by a decrease in investment activity and investment demand. The main factors limiting the inflow of investments are both economic and political significance.

Investment demand on the part of profitable enterprises is limited due to the low level of the profit rate, high level of taxation, growth of debts and nonpayments. Formation of investment attractiveness is a part of the investment management system, which summarizes the set of elements that are in relationships and relationships with each other and form a definite ordering, integrity, unity. Like any process, investing requires management and it is implemented through functions taking into account the actions of certain laws and principles.

To implement the process, investment resources are required as a set of material, financial, and intellectual resources. On the basis of the analysis, material resources are defined as the share of fixed assets; financial resources as a profit or its share; intellectual resources as the result of intellectual, mental, spiritual, and creative activity related to the intellectual product.

The modern investment policy is formed on the basis of previous experience of using and creating sources of financing analysis.

Investment attractiveness of the industries is connected, first of all, with the sources of investment, the problems of their obtaining, formation of conditions that allow the production of investment resources. There are several sources of investing in enterprises and organizations. Each of them has its own peculiarities of formation and some normative and legal conditions of their reception and realization (Table 1 ).

The effectiveness of investments depends on a system approach to problem-solving. Thus, at the macro level, the management of the investment process is related to the state regulation of the economy (Figure 1).

For example, for the agrarian sector of Ukraine, the activation of investment activity depends on state support.

The amount of budget funds in the total amount of investment has been reduced; the state is not the main subject of this process and can influence it through the system of taxes, loans, depreciation policy, privileges, and subsidies.

In modern economic relations, budget state investments as a source of investment should be directed to the basic strategic industries and directions, as well as to the development of the social sphere, which provides conditions for the development of production.

Thus, investing in highly profitable branches of production makes it possible to earn revenues, as these industries are efficient, knowledge-intensive, provide an expanded reproduction process, their products are competitive, which contributes to the economic and social development of the country.

Ukraine needs financial resources or investments in any form. The development of scientific, technical,

Table 1

Sources of enterprise investment

\begin{tabular}{|c|c|c|}
\hline Reasons restraining investment flow & Sources of production investment & $\begin{array}{l}\text { Conditions providing investment } \\
\text { in production }\end{array}$ \\
\hline $\begin{array}{l}\text { - Lack of control over the targeted use } \\
\text { of public investment }\end{array}$ & - State irrecoverable investment & $\begin{array}{l}\text { - State protectionism } \\
\text { - Provision of state guarantees of private loans } \\
\text { - Support for highly profitable production } \\
\text { - Funding for the social sphere }\end{array}$ \\
\hline - Budget deficit & $\begin{array}{l}\text { - Privileged/non-privileged state } \\
\text { loans }\end{array}$ & $\begin{array}{l}\text { - Combining public investment - share participation } \\
\text { of the state } \\
\text { - Foreign investments }\end{array}$ \\
\hline $\begin{array}{l}\text { - The decrease in depreciation fund and } \\
\text { imperfect taxation system } \\
\text { - Lack of own funds }\end{array}$ & - Own accumulated funds & $\begin{array}{l}\text { - Indexing according to the standard depreciation } \\
\text { inflation } \\
\text { - A tax that should stimulate the production } \\
\text { - Creating professional associations of commodity } \\
\text { producers }\end{array}$ \\
\hline $\begin{array}{l}\text { - Banks are disadvantaged due to the lack } \\
\text { of guarantees of loans repayment } \\
\text { - Political and economic instability }\end{array}$ & $\begin{array}{l}\text { - Commercial loans of banks and } \\
\text { other financial structures }\end{array}$ & $\begin{array}{l}\text { - State guarantee of loans of commercial banks } \\
\text { - Growth in the rating - the trust of the government } \\
\text { - Foreign Banking Investments }\end{array}$ \\
\hline $\begin{array}{l}\text { - Non-corporate equity } \\
\text { - The infrastructure of the securities market } \\
\text { is not developed } \\
\text { - Distrust of the population to money } \\
\text { as a means of accumulation in the form } \\
\text { of contributions } \\
\text { - Lack of stock ownership culture }\end{array}$ & $\begin{array}{l}\text { - Selling your stocks to physical and } \\
\text { partly legal entities }\end{array}$ & $\begin{array}{l}\text { - Corporate equity } \\
\text { - The openness of enterprise information } \\
\text { - Elimination of the psychological causes of inflation } \\
\text { - Indexing of population contributions } \\
\text { - Savings for the accumulation } \\
\text { - Formation of the right expectations of individuals }\end{array}$ \\
\hline
\end{tabular}




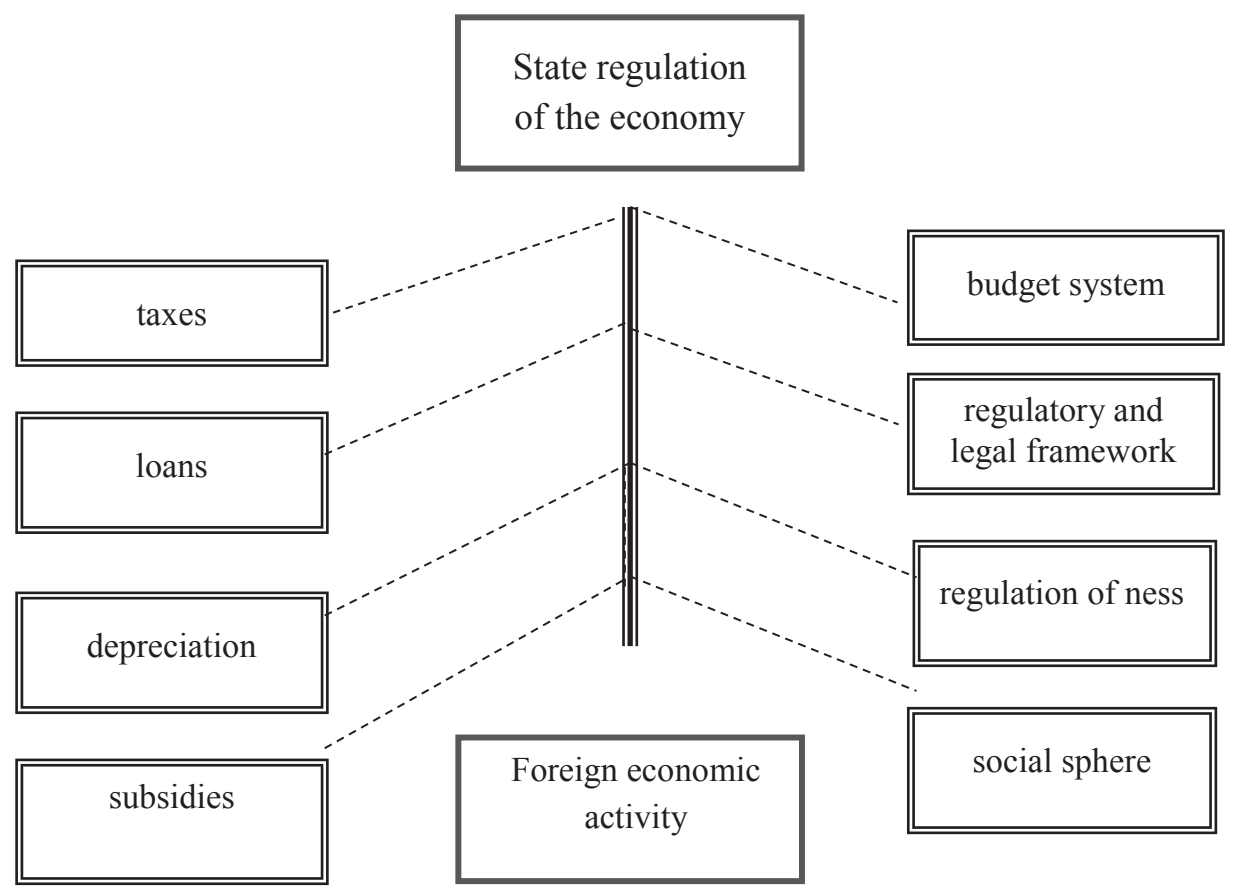

Figure 1. The system of state regulators of the investment process

and humanitarian potential, in particular, its intellectual component is one of the components of successful reforms in modern countries. Scientific and technological progress is becoming more and more financially capacious.

Investing in the social sphere is due to the qualitative improvement of the organization of production, carried out on an innovative basis, which will stimulate the investment attractiveness of industries. The social assessment of the effectiveness of investments depends and is determined by the system of assessments, which includes indicators of the level and quality of life.

One of the defining conceptual methodological aspects of socioeconomic reform in Ukraine is the resolution of the question of the relationship between the interests of man, society, and the state in the society, in practice this means that the interests of the person as the main object of investment should become the priority, and the interests of the state should be derivatives from them. It will contribute to the enrichment and effective development of the state, stabilizing its political and economic situation, as the socio-economic situation affects the inflow of investments into the country. When adopting an investment decision, a hierarchical scheme describing the basis of the values of life and society and shaping the image of the country is studied (Figure 2).

In the world, in the context of integration processes, information and knowledge become strategic goods; therefore, there is a reorientation of investments, first of all, investment of capital into a person. The state of the national economy and the welfare of citizens are determined and depend on the state authorities.
Formation the conditions that of the social benefits: national security, education, the environment medical care, the possibility of creativity, and others are the function of the state.

Obtaining state loans is complicated in the conditions of budget deficits. Therefore, the priority share of the state in the process of investment is preferred, as well as the state guarantees on the contrary to the private loans.

According to foreign economists, who analyse the economic situation in our country, state investments should not be connected with the support of unprofitable production, increasing taxes. Thus, the increase in various types of taxes leads to different consequences (Table 2).

Table 2

\section{Consequences of taxes rising}

\begin{tabular}{|l|l|l|}
\hline \multicolumn{1}{|c|}{ Taxes } & $\longrightarrow$ & \multicolumn{1}{c|}{ Consequences } \\
\hline For profit & $\longrightarrow$ & Reduced revenue \\
\hline Added value & $\longrightarrow$ & Inflation increases \\
\hline Selling & $\longrightarrow$ & Production is reduced \\
\hline $\begin{array}{l}\text { Use of means of production } \\
\text { and raw materials }\end{array}$ & $\longrightarrow$ & $\begin{array}{l}\text { The use of production } \\
\text { and raw materials } \\
\text { is reduced }\end{array}$ \\
\hline
\end{tabular}

The investment process allows getting profit by increasing the amount of capital invested and increasing the quality of capital used. Extensive development is associated with the amount of capital invested and contributes to the increase in the number of employees in production but does not imply a qualitative return on the operation of projects and is reflected in the dynamics of income received in the future. 


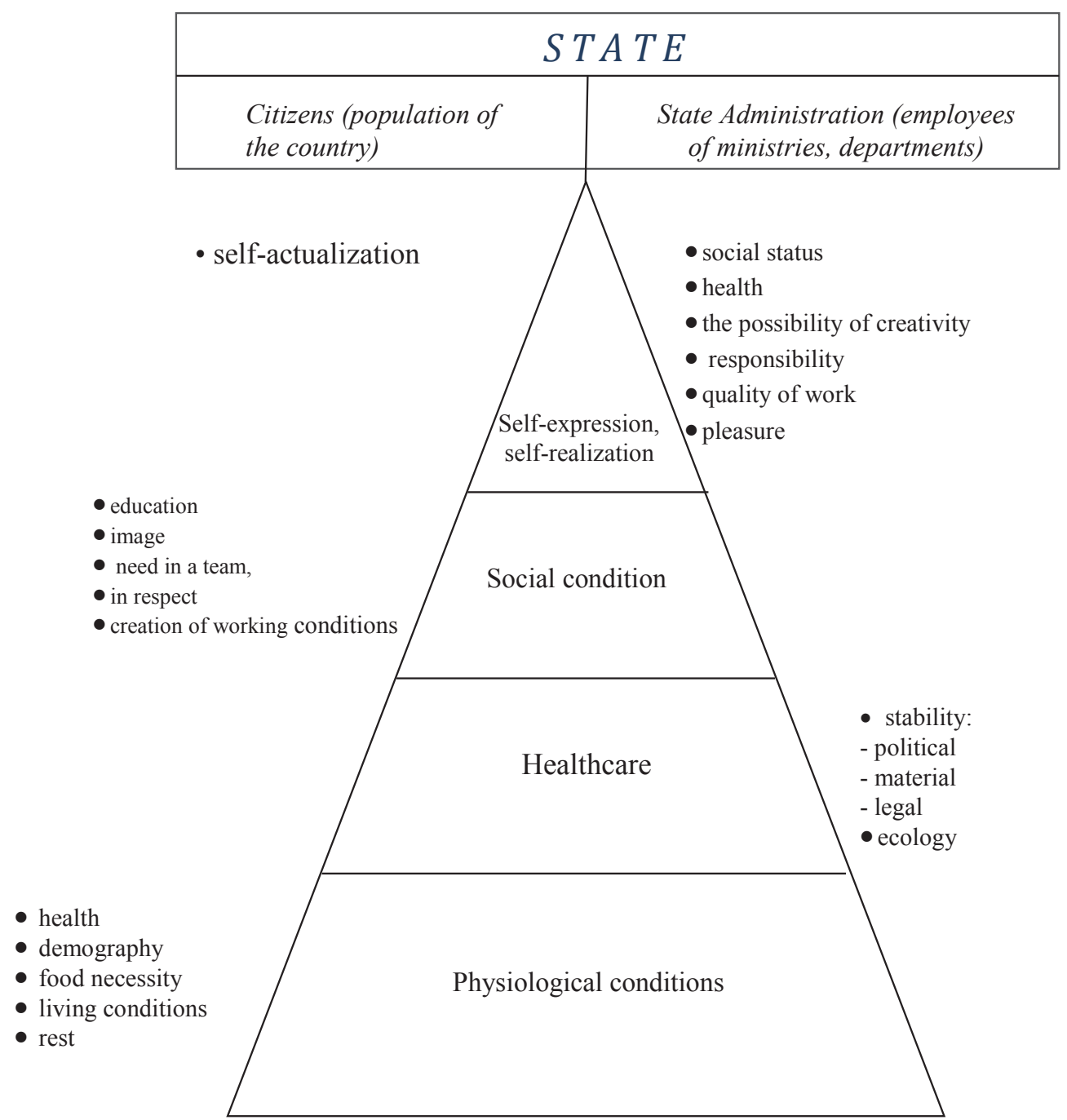

Figure 2. Scheme of the hierarchy of living values

Intensive investment involves the improvement of the quality of capital used on the basis of reorganization or technical re-equipment of the enterprise, increasing the level of professionalism of the personnel, creating new jobs, increasing the level of wages during the project.

Intensive development allows getting additional profit while improving the quality of investment. The increase in the capital should be optimized taking into account the marginal efficiency of investments because when investing more often, less profitable projects are implemented.

The main purpose of the investor is to receive profits for the accounting period. The size of profit can be expressed as a percentage of the investment cost, which is called the profitability of the investment or the level of profitability.

However, there is a general pattern - with an increase in investment, profitability is declining. Thus, the marginal efficiency of investments depends on the level of profitability, the volume of investments, and the quality of their use. There is feedback: the number of investments is increasing - the profitability or the amount of income derived from any activity is reducing. This is due to the effect of economic laws. Any company has the opportunity to receive certain benefits from investment activity, which is to increase profits.

\section{Profit as the main source of investing}

Not the amount of profit but the part that remains at its disposal is important in an investment process for an investor as it is a source of self-financing. An algorithm for financing or investing an object, which may be used by any enterprise or organization, is proposed (Figure 3).

Efficiently operating companies have the opportunity to independently form sources of own investment, which include, first of all, the profit remaining at the disposal of the enterprise, depreciation funds, formed reserve funds. Rational use of the sources of investment contributes to the achievement of the effect and is a factor affecting the investment attractiveness and priority. 


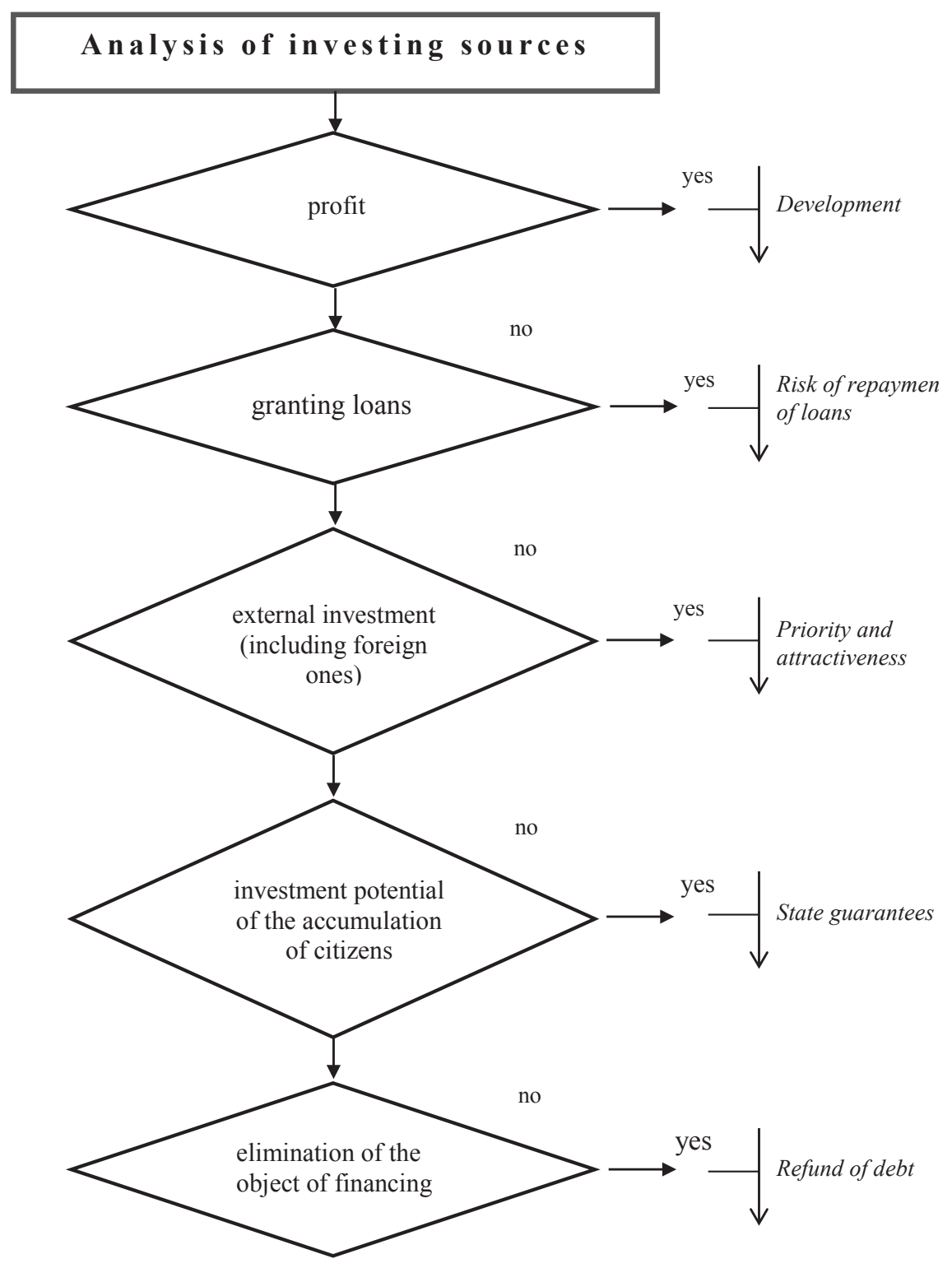

Figure 3. Algorithm for investing an object

The study of sources of self-financing of an enterprise allows determining profits as the main source of investment of enterprises. Profit is the basis of an investment decision and is considered from two positions:

- first: the profit received as a result of the production and sales of products (services);

- second: profit in the form of interest (dividends) received from the acquisition (contribution) of securities.

Profitability as a set of features that allow one or another moment to predict the level of company profits is estimated in monetary terms, taking into account such factors as the ability to successfully negotiate the terms of lending; positions on the market; level of technology; quality management; growth of the nominal value of the enterprise. In the course of the study, the factors that generate profit and the functions that make a profit are identified and analysed.

Factors and functioning meaning of the profit are presented in Figure 4. The factors considered are related and not interdependent; therefore, generating profit, they affect the degree of investment attractiveness and the development of the innovation process, being a part of it.

Innovations as a form of investment are involved in the process of continuous recovery, which includes all the changes that contribute to improving the company's activity in controlling the profitability of all units. Innovation process promotes innovation of the economy, improvement of working conditions; increases the level of mechanization and automation of labour-intensive processes; the professionalism of working people; quality management work, encouraging the development of innovative ideas, as well as the training of employees. 


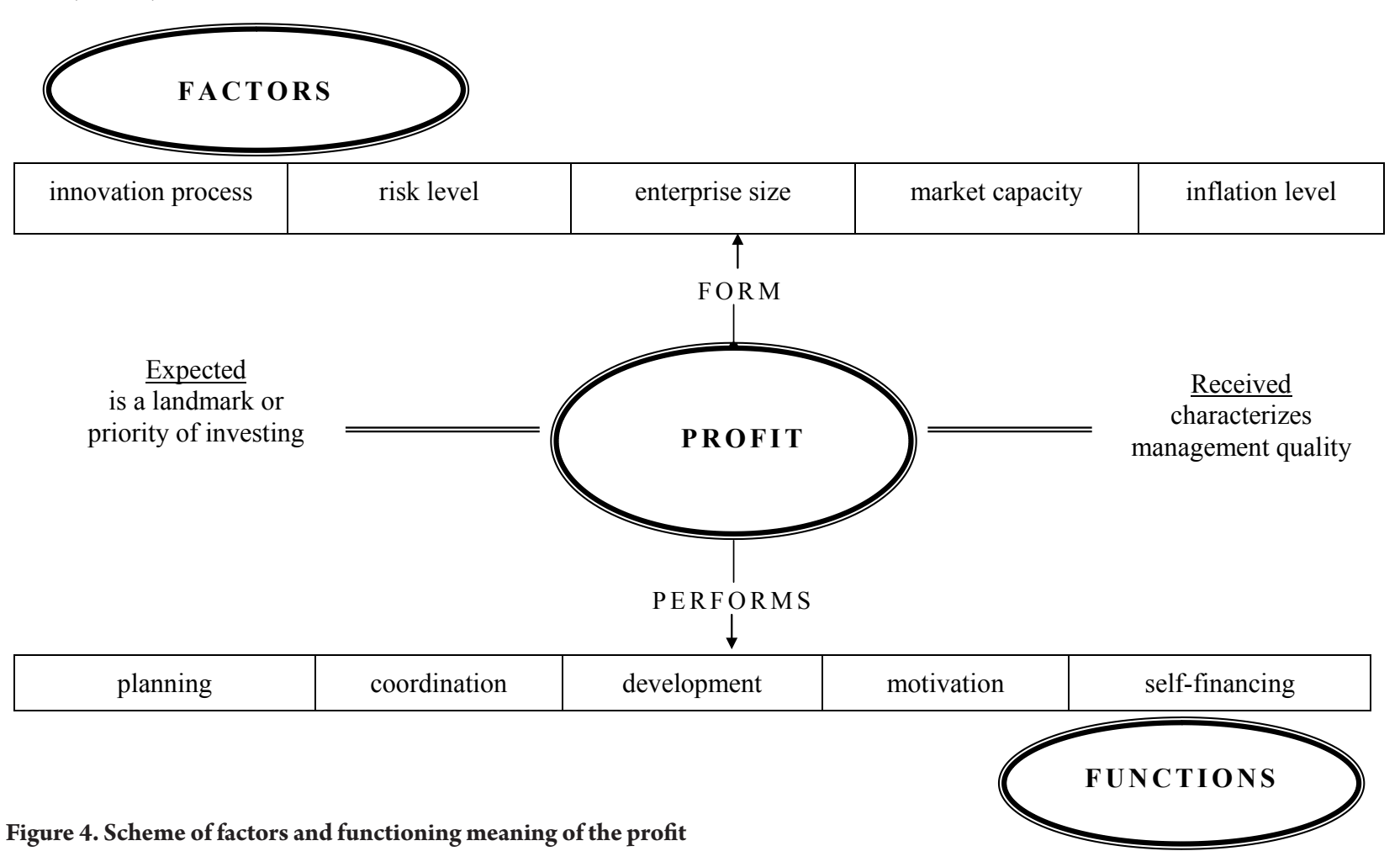

Investing in an innovation project requires justification and evaluation of its effectiveness.

On the basis of system analysis of innovation activity of the enterprise, one can determine its potential market opportunities and attractiveness for the investor, and profit growth is ensured mainly due to: production of new products; development of new markets; growth of labour productivity; use of new raw materials.

Large-scale enterprises expect higher technical and economic levels, which provide high productivity and level of payment. There is a direct relationship between the growth of the company/enterprise and the reduction of risks and the likelihood of bankruptcy, as large enterprises are more competitive, have the opportunity to diversify production and influence the market. But the factor of increasing the size of the company has a certain limit, as well as the tendency to stabilize the growth of profit or its decline, depending on the industry.

Factor dependence between profit and market is determined by the fact that the investor prefers the most profitable assets or investment products with the maximum rate of return on invested capital, the enterprise must strive to effectively use its competitive advantages, which provide it with economic stability in market unstable relationships and income generation. Depending on the number of enterprises in the region that produces investment goods, the level of competition and the price of sales are determined.

Predictable, expected profit is determined by calculation as the basis of taxation. The expected level of return on investment contributes to their increase and, conversely, decreasing profits decrease the demand for investment goods. The alternative to direct investment is to invest money in the bank in order to obtain an interest rate.

Profit is influenced by the level of inflation, which reflects an increase in the average price level in the economy, and without state regulation of the inflation process, the profit becomes a mechanism for the redistribution of funds of depositors and taxpayers to traders and bankers.

Factors that generate profits lead to a number of functions that affect the investment process. Based on priorities, the investment and management quality that affects expectations and profits can be distinguished by the following revenue-generating functions:

- planning based on the fact that the expected profit is the basis for the investment decision;

- coordination is related to the development of investments;

- development, since the profit is determined by the success of the activity and the quality of management; - self-financing, due to the fact that a part of the profit received is a source of financing for development or reproduction/reinvestment;

- motivation characterizing the profitability of investments related to the purpose of investment activity.

These functions can be considered as classical interdependent because they find content only in the conditions of their existence and contribute to the development of production. 
The considered functions directly result from the development of the enterprise and depend on the adoption of investment decisions. The role of the profit in the adoption of an investment decision depends on its type: short-term expected profit is a complete selffinancing, which implies the rapid implementation of investments.

Long-term expected profit is related to the cycle of goods production. The values of profit expected for a number of years are formed under the condition of measurement in identical units, that is, are calculated for the calculation period or discounted. In the developed countries, the only possible criterion for the direction of investment processes is to obtain maximum returns (in the short-term, medium-term, and long-term plans).

In the public sector, the criteria for the investment decisions are based on the criterion of the general benefits or benefits of the producer. Any field of the economy or economic system cannot exist without the criterion that determines the distribution of investments between industries and enterprises. The investment process should not be limited to forecasting profit because it is necessary to manage the process of obtaining it.

\section{Conclusions}

The investment system at all levels of management should include and combine possible sources of investment in production to the internal resources of the business entity. It positively affects the effectiveness of the investment process and, as a result, will increase the welfare of the society, ensure its development in the future on the basis of the vital values. Any enterprise has the opportunity to benefit from investment activities, which is to increase profits. In an investment process for an investor, it's not the amount of profit as such, but the part that remains at its disposal and can be used as a source of self-financing. The state supports the priority sectors of the economy; therefore, profit is distributed unevenly across industries. Industry, transport, communications, and banking system have a constant profit, unlike the unprofitable agriculture sector.

Our country has great scientific, human, and technological potential, rich natural resources for economic development. Their contribution to the development of the state is possible through the merger of foreign and domestic investors. Reforming the economy through the unification of Ukrainian and foreign capital contributes to the national interests of Ukraine and makes it more attractive for investment.

\section{References:}

Zakon Ukrainy vid 18.09.1991 № 1560-XII «Pro investytsiinu diialnist», zi zminamy ta dopovnenniamy [Law of Ukraine dated 18.09.1991 No. 1560-XII "On Investment Activity", as amended and supplemented]. Retrieved from: http://zakon.rada.gov.ua/go/1560-12

Babo Anre (1993). Prybyl [Profit] / prevod s frantsuzkoho. Moskva: Prohress.

Postanova Kabinetu Ministriv Ukrainy «Pro zatverdzhennia Prohramy rozvytku investytsiinoi ta innovatsiinoi diialnosti v Ukraini» № 389 vid 02.02.2011 [Resolution of the Cabinet of Ministers of Ukraine "On Approval of the Program for the Development of Investment and Innovation Activity in Ukraine" No. 389 dated February 2, 2011]. Ofitsiinyi visnyk Ukrainy. Retrieved from: http://zakon. rada.gov.ua/laws/show/389-2011-p

Pereverzieva, A. V. (2016). Otsinka suchasnoho stanu zaluchennia inozemnykh investytsii v ekonomiku Ukrainy [Assessment of the current state of attraction of foreign investments into the Ukrainian economy]. Retrieved from: http://www.irbis-nbuv.gov.ua/.../cgiirbis_64.exe?

Leshanych, L. V., Hunda, S. V. (2015). Rozvytok investytsiinoi pryvablyvosti v Ukraini ta shliakhy podolannia investytsiinoi kryzy [Development of investment attractiveness in Ukraine and ways to overcome the investment crisis]. Retrieved from: https://dspace.uzhnu.edu.ua/.../

Kovalenko, O. V., Tymofieieva, K. (2011). Priorytetni napriamky inozemnoho investuvannia v Ukraini [Priority directions of foreign investment in Ukraine]. Retrieved from: http://www.zgia.zp.ua/gazeta/evzdia_1_078.pdf

Krykhivska, N. O., Chernyshova, H. M. (2017). Investytsiina pryvablyvist Ukrainy: osnovni problemy ta shliakhy yikh vyrishennia [Investment attracti veness of Ukraine: main problems and ways of their solution]. Retrieved from: http://www.economyandsociety.in.ua/journal/9_ukr/45.pdf

Herzanych, V. M. (2014). Osnovni nedoliky ta problemy zaluchennia inozemnykh investytsii v Ukraini [The main drawbacks and problems of attraction of foreign investments in Ukraine]. Efektyvna ekonomika. Retrieved from: http: / /www.economy.nayka.com.ua/n=4\&y=2014

Pavlovych Adam (2000). Zaluchennia priamykh inozemnykh investytsii v ekonomiku Polshchi [Attraction of direct foreign investments into the economy of Poland]. Viden.

Sait Derzhavnoi sluzhby statystyky Ukrainy [Site of the State Statistics Service of Ukraine]. Retrieved from: http://www.ukrstat.gov.ua

Investytsii zovnishnoekonomichnoi diialnosti Ukrainy (2014). Statystychnyi zbirnyk Derzhavnoi sluzhby Ukrainy.

Fernandes (1996). Rol hosudarstva v selskom khoziaistve v ahropromyshlennosty [The role of the state in agriculture and agribusiness]. Doklad na semynare Verkhovnoho Soveta Ukrainy. 